\title{
FACTORS IN THE ADOPTION OF TREE CONSERVATION PRACTICES BY UPLAND FARMERS IN SOUTHERN LEYTE 1 I
}

\author{
Anatolio N. Polinar \\ Instructor, College of Forestry \\ Leyte State University \\ Visca, Baybay, Leyte \\ and \\ Antonia Cecilia Y. Sandoval \\ Professor, College of Education \\ Leyte State University \\ Visca, Baybay, Leyte
}

\begin{abstract}
This study revealed that upland farmers in Southern Leyte had been practicing tree conservation by planting and protecting trees and implementing local forestry laws within their farm and communities. Farmers also assisted in disseminating information to raise people's awareness on the importance of tree conservation. Results also showed that organization affiliation, tenure status, personal contacts and mass media had significant relationship to the adoption of tree conservation practices.
\end{abstract}

KEY WORDS: Factors. Adoption. Trees. Conservation practices. Upland farmers.

1I Part of MS thesis of the senior author 


\section{INTRODUCTION}

The Philippines is considered by Conservation International as biological hot spot on the basis of the number of species, their degree of endemism and the seriousness of threat posed to biodiversity (Freeman, 1998). For flora alone, $5 \%$ of the endemic Philippine species have already been lost. This is the result of the loss of $90 \%$ of the forest habitat through uncontrolled degradation of air, water pollution, wars, pressure from agriculture and other industries, increasing human needs and environmental mismanagement. The current level of destruction of forest has called the attention of environmentalists, foresters and development individuals to the urgent need for action. As communities of underprevileged farmers draw on the forests for their most basic and urgent needs, the destruction of ecosystem has preceeded without limitation.

The significance of forest tree conservation to socib-economic development of communities cannot be over-emphasized. It is generally held that man has always been the major causal agent in the degradation of our tree species and its habitat (Quero, 1998). Among the upland activities of farmers, burning has always resulted into destruction of forests. On the other hand, upland farmers and forest users are also known to have valuable knowledge in using and nurturing tree diversity (Castro, 1998). They have a comprehensive knowledge about the plants and animals of their world and even the strategies for conservation.

The upland farmers, like any other individuals, have distinct attributes and characteristics which may influence their views, opinions and/or anticipation towards an object, idea or innovation (Amihan, 1981). Such viewpoints, in turn, may determine to some extent the behavior they are going to exhibit in a particular situation. It is believed that the level of adoption of tree conservation practices is influenced by the socio-demographic, economic, agricultural and communication/trainingrelated factors (Figure 1). 
The study was conducted to determine the effects of certain factors on the adoption of tree conservation practices by upland farmers in Southern Leyte.

Conceptual Framework

Independent Variables

Dependent Variables

Upland Farmers' Characteristics

Socio-demographic

*Age

* Sex

${ }^{*}$ Civil status

* Educational attainment

* Number of dependents

* Organizational affiliation

Economic and Agricultural Factors

* Standard of living

* Annual gross income

* Size of farm

* Tenurial status

* Farming experiences

Communication and Training. related Factors

* Personal contact

* Mass media

*: Training/seminar

* Training needs

Figure 1. Schematic diagram showing the relationship of socio-demographic, economic, agricultural and communication/training-related factors to adoption of tree conservation practices. 


\section{METHODOLOGY}

This study was conducted in Maasin City and in five municipalities of Southern Leyte, namely: Bontoc, Sogod, Libagon, Saint Bernard and Hinunangan on the basis of the existence of a forest and DENR people-oriented social forestry project in the area.

Respondents of the study were farmers in the abovementioned localities covered by the Social Forestry Program. The respondents were chosen using the following formula (Amihan, 1981):

$$
n=\frac{N}{1+N(e)}
$$

where:

$$
\begin{aligned}
& n=\text { desired number of sample farmers } \\
& N=\text { total number of upland farmers } \\
& e=\text { precision error desired }
\end{aligned}
$$

Farming experience was defined as the number of years that the respondents had been engaged in farming. This was used to categorize farmers into those who have had long farming experiences and those who have had a short farming experience equal or below the mean were considered as farmers who had a short farming experience.

To get an index of tree conservation practices, each practice reported was given a score of 1 . Those who did not adopt any tree conservation practice were given zero. Respondents whose scores fell below the mean were considered as farmers with low level of adoption, and high for those farmers whose scores were equal to or above the mean. Chi-square test was used to determine the relationship between socio-demographic, economic, agricultural and communication/trainingrelated factors and the adoption of tree conservation practices. 


\section{RESULTS AND DISCUSSION}

Tree conservation was not new to upland farmers in Southern Leyte. They had been practicing conservation in their own way based on the local knowledge they acquired from their forefathers. Tree planting or adoption of tree species in individual farm lots (Table 1) was the most common method/approach used by the farmers in Southern Leyte. As a way of conserving the forest, on-farm trees and inducing the evolution of undergrowth of different species, majority of the farmers planted yemane (Gmelina arborea Roxb.), large leaf mahogany (Swietenia macrophylla (King), mangium (Acacia mangium (Willd), white lauan (Shorea contorta (Merr \& Rofle), red lauan (Shorea negronensis (Foxw.), agoho (Casuarina equisetifolia (Lin.), auri (Acacia auriculiformis A. Cunn. ex. Benth.) and molave (Vitex parviflora (Juss.) to their farm lots, backyards and even along road sides. Even before the implementation of the massive reforestation program of the government, the respondents had already started planting trees based on knowledge of the value of the different species. They planted trees for future use, particularly for their housing needs.

Table 1. Tree conservation practices adopted by respondents in Southern Leyte, 2000.

\begin{tabular}{lcc}
\hline \hline \multicolumn{1}{c}{ Practices } & $\begin{array}{c}\text { Frequency } \\
\left(n=180^{*}\right)\end{array}$ & Rank \\
\hline Tree planting/reforestation/tree farming & 168 & 1 \\
Management and protection of farm trees & 163 & 2 \\
Implementation of local policies & 73 & 3 \\
Advocacy and information system & 63 & 4 \\
Creation of local organization & 55 & 5 \\
\hline
\end{tabular}

* multiple response 
Management and protection from cutting farm trees was another local strategy practiced by the upland farmers. Cutting of bagalunga (Melia dubia Cav.), ipil-ipil (Leucaena leucocephala (Lam.) de Wit.), anislag (Securinega flexousa Muell. Arg.) and anie (Erythrina fusca Lour) was prohibited. These species provided shade to abaca plantation and contributed organic matter which served as organic fertilizer to the growing crops. As to utilization, dead trees and fallen logs provided firewood for use by the respondents.

According to some respondents, the implementation of local. policies related to tree conservation and management was a practice adopted by the constituents in the community. Local government units enacted and implemented resolution and ordinances prohibiting individuals from cutting trees of any kind and establishment of kaingin farm without permission from concerned authorities.

\section{Socio-Demographic Variables and Respondents' Adoption of Tree Conservation Practices}

Respondents' organizational affiliation and their adoption of tree conservation practices would imply that affiliation with organization tended to influence their motives to adopt conservation practices. Membership in organization provided the people with the chance to socialize and influence each other's interests/ideas. It also influenced their awareness towards an innovation/development in the environment (Table 2).

Older farmers were more ready to adopt the innovation than their younger counterparts since they valued new ideas that satisfied their needs, physical maturity and experience. As to civil status, married respondents played more varied roles, participated in and adopted different practices in consonance with their responsibilities. Higher adoption was observed compared to unmarried individuals. Likewise, the number of dependents of a person also influenced the adoption of tree conservation practices. 
Table 2. Socio-demographic factors and the adoption level of tree conservation practices by respondents in Southern Leyte.

\begin{tabular}{cc}
\hline \hline Socio-Demographic Factors & $\mathrm{X}^{2}$ value \\
\hline Age & 1.08 \\
Sex & 0.11 \\
Civil status & 0.73 \\
Educational attainment & 0.84 \\
Number of dependents & 2.56 \\
Organizational affiliation & $4.18^{*}$ \\
\hline \hline
\end{tabular}

${ }^{*} p<.05$

Economic and Agricultural Variables and Respondents' Adoption of Tree Conservation Practices

Among the variables, tenure status showed significant relationship to the adoption of conservation practices (Table 3 ). This implies that owner-operators were more aware of the different conservation practices in their environment. They could easily adopt such practices because they hàd the freedom to decide and do things on their own farms to maximize production. Further, they were not afraid to take more risks

On the other hand, farmer's standard of living, annual gross income, size of farm and farming experience were not significantly related to the adoption level of conservation practices. However, as expressed by upland farmer-respondents, these variables may have influenced the adoption level of an innovation. According to them, farmers with higher annual gross income perceived and expected more from the adoption of an innovation. Similarly, farmers with bigger landholdings adopted easily varied conservation measures than farmers with smaller farm size. Those with bigger landholdings planted more trees than subsistence upland farmers. Farmers who were employed in reforestation projects and had gained much experience in tending trees readily adopted conservation measures than farmers without experience. 
Table 3. Economic and agricultural factors and the adoption level of tree conservation practices by respondents in Southern Leyte.

\begin{tabular}{lc}
\hline \hline Economic and Agricultural Factors & $\mathrm{X}^{2}$ value \\
\hline & \\
Standard of living & 0.16 \\
Annual gross income & 2.15 \\
Size of farm & 0.20 \\
Tenure status & $4.77^{\star}$ \\
Farming experience & 0.22 \\
\hline \hline$p<.05$ &
\end{tabular}

Information Sources and Respondents' Adoption of Tree Conservation Practices

Exposure to personal contacts and the adoption level of tree conservation practices were significantly related (Table 4). Respondents with low exposure to personal contacts, media sources and low adoption level while those with high exposure tended to have higher adoption of tree conservation practices. This implies that the more personal contact the farmers had with DENR officials/technicians, friends, neighbors or their fellow farmers, the greater the awareness of tree conservation practices. Thus, personal communication channels should be strengthened especially in the upland communities to disseminate recent technology/innovation more effectively.

Significant relationships were also observed between exposure to mass media and adoption level of tree conservation practices (Table 4). This finding indicates that the more exposure to mass media sources a person had, the more knowledge he could obtain and consequently, the stronger were his motives to adopt innovations. Exposure to mass media sources like radio, magazines and other printed materials could elevate the level of understanding of the farmers towards adoption of an innovation. 
Training-related factors were significantly related to the adoption of tree conservation practices. However, as expressed by the farmers and based on field observations, trainings and seminars could also serve as sources of new learning and information. These could be the factors that influenced people's attitudes, perceptions and future decisions in the adoption or non-adoption of new technologies.

Table 4. Communication sources and training-related factors and the adoption level of tree conservation practices by respondents in Southern Leyte.

\begin{tabular}{ll}
\hline \hline Communication Sources and & $\mathrm{X}^{2}$ Value \\
Training-Related Factors & \\
\hline
\end{tabular}

Personal contacts

$22.67^{* *}$

Mass media

$6.59^{*}$

Training-related factors

0.04

${ }^{\star} p<.05 ;{ }^{\star \star} p<.01$

\section{Suggestions to Promote Conservation Practices in Southern Leyte}

To promote tree conservation practices in Southern Leyte more effectively, dissemination of information through trainings and seminars ranked 1. This is to raise the level of awareness of the upland constituents on tree conservation. Others suggested that the DENR technician should visit farmers' farm and establish model farm sites (Table 5). 
Table 5. Suggestions to effectively disseminate and increase adoption of tree conservation practices in Southern Leyte*.

Suggestions

Frequency

Rank

seminars in farmers' respective localities

Frequent visitation by technician in farmers' farm

Establishment and maintenance of model

farm site as show window for on tree conservation

Provision of tenure to planted trees

Enough planting materials be distributed to farmers

Strengthen organization through capability building in using the technology

168

161

129

118

112

3

106

Advocacy to be conducted especially among passive upland farmers

Promotion of tree conservation program through

radio and other communication media

.76

9

Conduct of values education training program for upland farmers

57

Assurance of market for forest products produced

by farmers

46

\section{CONCLUSION AND RECOMMENDATION}

Based on the data, the following conclusions can be drawn:

1. Upland farmers in Southern Leyte have adopted local tree conservation practices; 
2. Socio-demographic, economic, agricultural, communication and training related factors have influenced the adoption behavior of farmers. Organizational affiliation, tenure status, personal contacts and mass media have greatly influenced the farmer's level of adoption of tree conservation practices.

It is recommended that the DENR should conduct a massive information campaign concerning conservation of trees through personal contacts and radio/TV programs. Seminar-workshops should also be conducted in strategic places to promote advocacy and awareness on the importance of tree conservation.

\section{LITERATURE CITED}

AMIHAN, B.T. 1981. Leyte Farmers' Perception and Expectation from the National Coconut Planting/Replanting Program. NCP/RP. pp. 178.

CASTRO, N.T. 1998. Biodiversity conservation practices of the Agtas Northern Sierra Madre. Paper presented during the Local Knowledge and Biodiversity National Workshop on October 19-22, 1998. Visayas State College of Agriculture, Baybay, .Leyte, Philippines. pp. 1-7.

FREEMAN, J. 1998. Biodiversity: Use it or lose it. Paper presented during the Local Knowledge and Biodiversity National Workshop on October 19-22, 1998 at ViSCA, Baybay, Leyte. pp. 1-5.

QUERO, J.V. 1998. Experience in forest protection and the implication for the training of forestry. Paper presented during the Local Knowledge and Biodiversity National Workshop on October 19-22, 1998. ViSCA, Baybay, Leyte, Philippines. pp. 1-2. 


\section{ABOUT THE AUTHOR}

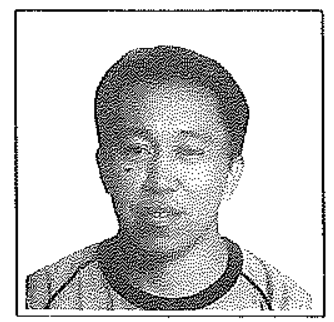

The author finished his Bachelor of Science in Forestry and the Master of Science degree major in Agricultural Extension from the then Visayas State College of Agriculture (ViSCA), now the Leyte State University (LSU).

After finishing his extension course, he pursued graduate studies at Georg-August University, Gottingen, Germany leading to the degree Master of Science in Tropical and International Forestry under the German Academic Exchange Program (DAAD).

Presently, he is an Instructor of the Department of Forest and Wildlife Management and Conservation (DFWMC) of the College of Forestry, Leyte State University, Visca, Baybay, Leyte.

The co-author is a professor of the College of Education, Leyte State University and the major adviser of the senior author. 